\title{
Fibrosarcoma of the trachea with severe tracheal obstruction
}

\author{
A.J.R O NCOR ONI, R.J.M.PUY, E. G O L D M A N, \\ R. FONSECA, and GLORIA OLMEDO
}

Centro de Rehabilitacion Respiratoria 'Maria Ferrer', Dr. Enrique Finochietto 849, Buenos Aires, Argentina

\begin{abstract}
Roncoroni, A. J., Puy, R. J. M., Goldman, E., Fonseca, R., and Olmedo, G. (1973). Thorax, 28, 777-781. Fibrosarcoma of the trachea with severe tracheal obstruction. A patient with a tracheal fibrosarcoma is reported. The tumour was located just above the thoracic inlet and produced severe obstruction predominantly during expiration. An abnormal effort independent flow pattern was seen during inspiration in isovolume pressure-flow studies. Endoscopic resection induced temporary symptomatic remission, and airway resistance and expiratory flows became normal. Subsequently he required resection of eight tracheal rings with end-toend tracheal anastomosis. Obstructive granulomata then developed at the suture sites, necessitating endoscopic removal. Later tracheal stenosis responded to periodic dilatation.
\end{abstract}

A patient with severe tracheal obstruction due to a fibrosarcoma was studied by lung function tests before treatment, after endoscopic resection, and again after surgical excision of the tumour.

\section{METHODS}

Lung function studies were performed with the subject sitting in a volume displacement body-plethysmograph. Airflow was measured at the mouth with a heated pneumotachograph and mouth pressure with a Statham transducer PR 23-ID-300. Functional residual capacity (FRC) and airway resistance (Raw) at a thoracic gas volume (TGV) near FRC were measured by a modification (Jaeger and Otis, 1964) of a technique previously described by DuBois et al. (1956) and DuBois, Botelho, and Comroe (1956). Conductance (Gaw) and specific conductance (SGaw) were computed from Raw and TGV. Maximal effort expired and inspired vital capacity manoeuvres were performed and traced on the same recorder. From these recordings forced vital capacity (FVC), forced expiratory volume in one second $\left(F E V_{1}\right)$, maximal expiratory or inspiratory flows (MEF, MIF), and maximal flow rate at 50\% FVC (MEF $\left.50, \mathrm{MIF}_{50}\right)$ were calculated. An oesophageal balloon was placed in the lower third of the oesophagus (Milic-Emili, Mead, Turner, and Glauser, 1964). Transpulmonary pressure (oesophagus-mouth) was measured with a differential pressure transducer (Statham PR23-ID300). Static recoil pressure (Pst (1)) of the lungs was measured by the flow interruption method during deflation from total lung capacity (TLC) to FRC (Mead, Turner, Macklem, and Little, 1967). Alveolar pressure (Palv) was obtained from Pst (1) and transpulmonary pressure at a given volume. Isovolume pressure-flow (IVPF) curves were obtained from vital capacity manoeuvres after varying effort. During

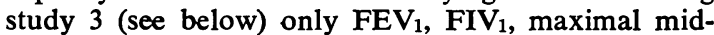
expiratory flow rate (MMEFR), and maximal midinspiratory flow rate (MMIFR) were measured in a 131 . Collins spirometer.

\section{CASE REPORT}

The patient was a 13-year-old girl. Ten months before admission she had complained of productive cough, breathlessness, and noisy breathing; a tracheal adenoma was suspected and she was referred to our hospital for assessment and treatment. On admission dyspnoea and tracheal stridor appeared when breathing was exaggerated by slight exertion. The physical examination was otherwise normal. Tracheal tomography showed an opacity in the middle third (Fig. 1). A lateral radiograph revealed a tumour in the cervical trachea near the thoracic inlet (Fig. 2). The blood count, ESR, urinalysis, serum proteins, blood gases, and $\mathrm{pH}$ were normal. Bronchoscopy revealed a voluminous mass in the middle third of the trachea which almost completely obstructed the lumen. The tumour was soft and friable. Bleeding during biopsy made it necessary to resect by diathermy coagulation. After this procedure the signs of the obstructed breathing disappeared and the tracheal tomogram was normal but an irregularity in the posterior tracheal wall was still present in the lateral radiograph and on tracheography. The biopsy specimen consisted of multiple small fragments of 


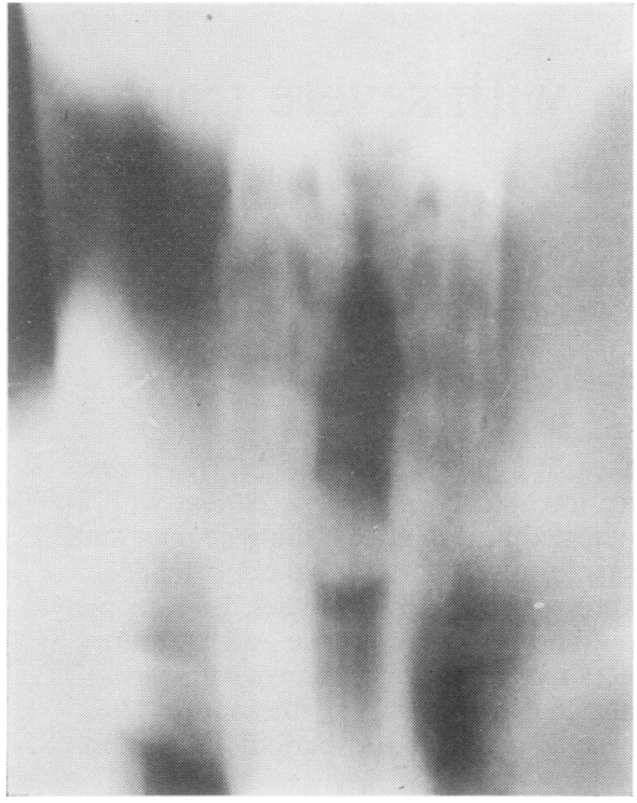

FIG. 1. Tracheal tomogram.

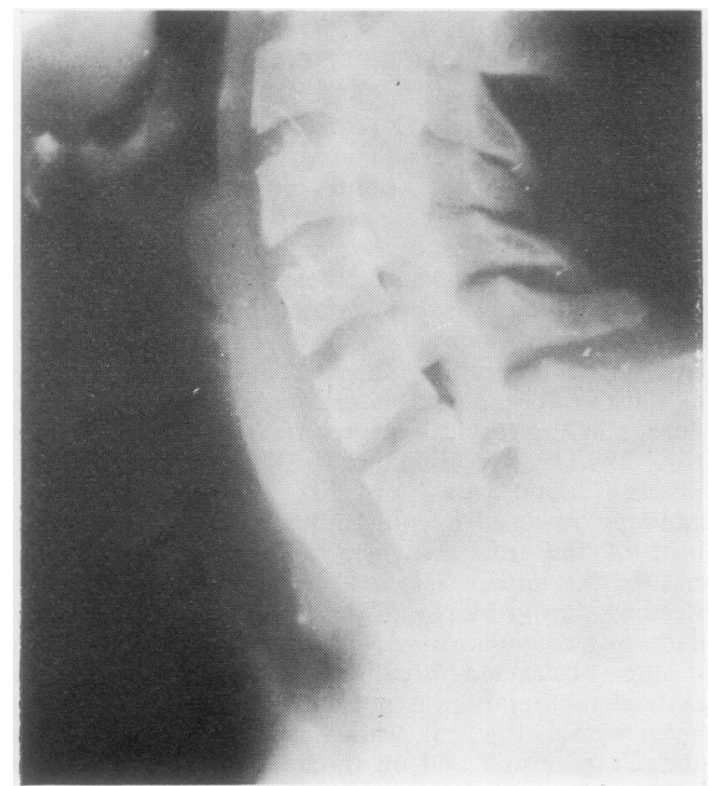

FIG. 2. Lateral radiograph of trachea.

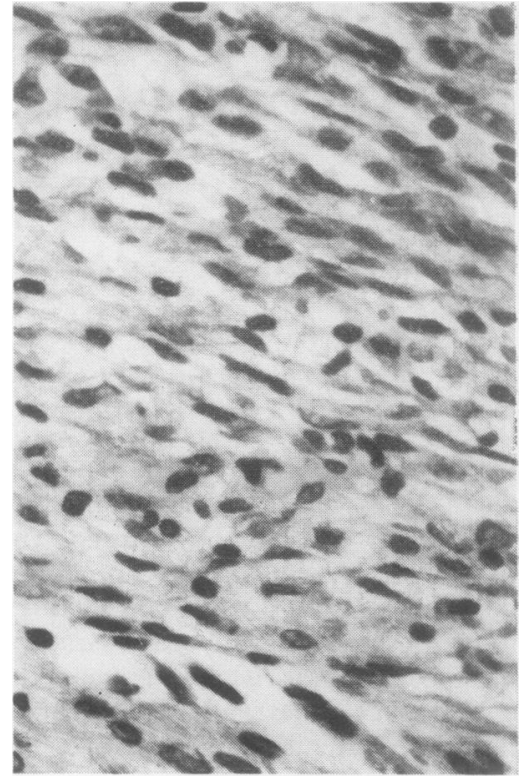

FIG. 3. A well differentiated fibrosarcoma with spindle cells and elongated nuclei. No mitoses are seen in this field (Haematoxylin and eosin $\times 300)$.

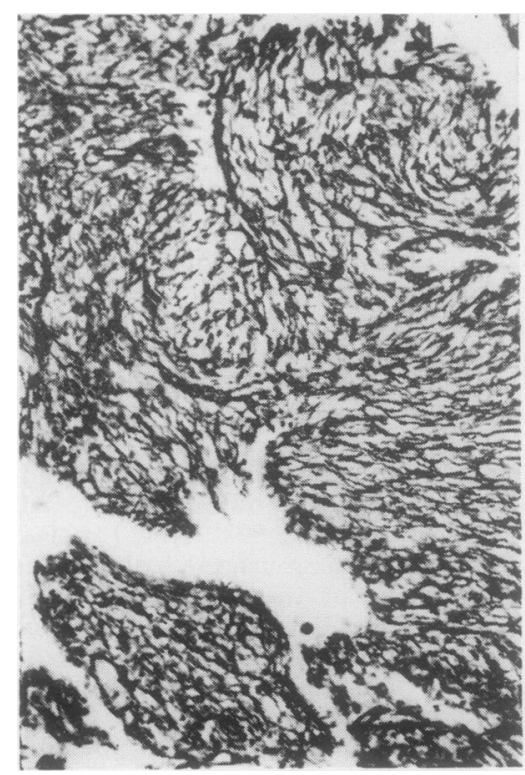

FIG. 4. Gomori's reticulin stain showing abundant, delicate fibres surrounding the cells. $(\times 50)$ 
T A B LE I

PHYSICAL CHARACTERISTICS AND LUNG MECHANICS

\begin{tabular}{|c|c|c|c|c|c|c|c|c|c|c|}
\hline Sex & $\begin{array}{l}\text { Age } \\
(\mathrm{yr})\end{array}$ & $\begin{array}{c}\text { Weight } \\
\text { (kg) }\end{array}$ & $\begin{array}{c}\text { Height } \\
\text { (cm) }\end{array}$ & & $\begin{array}{l}\text { TLC } \\
\text { (1.) }\end{array}$ & $\begin{array}{l}\text { VC } \\
\text { (l.) }\end{array}$ & $\begin{array}{c}\text { FRC } \\
\text { (1.) }\end{array}$ & $\underset{\text { (l.) }}{\mathbf{R V}}$ & RV/TLC & $\begin{array}{l}\text { Pst (1) } \mathrm{cmH}_{2} \mathrm{O} \\
\text { at } 90 \% \mathrm{TLC}\end{array}$ \\
\hline F & 13 & $41 \cdot 5$ & 148 & $\begin{array}{r}\text { Predicted } \\
\text { Study } 1 \\
\text { Study } 2 \\
\text { Study } 4\end{array}$ & $\begin{array}{l}3 \cdot 41 \\
4 \cdot 37 \\
4 \cdot 23 \\
3 \cdot 67\end{array}$ & $\begin{array}{l}2 \cdot 60 \\
1 \cdot 97 \\
2 \cdot 56 \\
2 \cdot 37\end{array}$ & $\begin{array}{l}1 \cdot 66 \\
3 \cdot 23 \\
2 \cdot 42 \\
2 \cdot 00\end{array}$ & $\begin{array}{l}0.83 \\
2.40 \\
1.67 \\
1.30\end{array}$ & $\begin{array}{l}0 \cdot 24 \\
0 \cdot 55 \\
0 \cdot 39 \\
0 \cdot 35\end{array}$ & $\begin{array}{l}16.6 \\
16.5 \\
15.4 \\
15.0\end{array}$ \\
\hline
\end{tabular}

Abbreviations as in text, RV=residual volume. Predicted values for lung volumes according to Zapletal et al. (1969); for Pst (1) according to Zapletal, Misur, and Samanek (1971).

greyish tissue. Closely packed spindle cells with fusiform oval nuclei were seen on microscopy (Fig. 3). There were no bizarre nuclei and only an occasional mitosis was found. The cells showed a tendency to be arranged in undulating bundles. The reticulin framework was prominent with delicate fibres around the cells (Fig. 4). Masson's trichrome stain for collagen showed abundant intercellular collagen. The picture was that of a well differentiated fibrosarcoma.

Several months after the first bronchoscopy a new biopsy of a small flat tumour on the left posterior tracheal wall showed a fibrosarcoma with submucosal infiltration. Tracheal resection with end-to-end anastomosis was then performed. The length of the excised segment was $4 \mathrm{~cm}$ and included eight tracheal rings. Residual tumour tissue was present and replaced the posterior aspect of the trachea but the adventitia was not involved. On the mucosal aspect it formed a plaque-like white ulcerated area, measuring $1.7 \times$ $1.4 \mathrm{~cm}$, about $8 \mathrm{~cm}$ above the carina but the resection edges were free from tumour. The histological appearance was identical with the biopsy specimen. The postoperative course was uneventful, but lung function tests four weeks after operation disclosed evidence of increasing tracheal obstruction and bronchoscopy showed several granulomata around the sutures. Both the sutures and granulomata were removed with temporary disappearance of air-flow obstruction. However, during the next six months obstructive symptoms reappeared on several occasions and he required periodic bronchoscopic dilatation. For the last three months the patient has been free of symptoms and the spirometric tests have remained normal.

\section{RESULTS OF LUNG FUNCTION TESTS}

Preoperative measurements (study 1) showed hyperinflation with decreased vital capacity and normal static recoil pressures and compliance (Table I). Airway resistance was markedly increased. Expiratory or inspiratory flows were both much lower than normal but expiration was predominantly affected, as shown by low ratios of $\mathrm{MEF} / \mathrm{MIF}, \mathrm{MEF}_{50} / \mathrm{MIF}_{50}$, and flow-volume pattern (Table II, Fig. 5). An abnormal pressureindependent pattern was shown in IVPF curves during inspiration. On expiration a definite flow plateau was not obtained despite alveolar pressures of more than $50 \mathrm{cmH}_{2} \mathrm{O}$ (Fig. 6).
T A B LE I I

LUNG MECHANICS

\begin{tabular}{|c|c|c|c|c|c|}
\hline & \multicolumn{4}{|c|}{ Study } & \multirow{2}{*}{ Predicted } \\
\hline & 1 & 2 & 3 & 4 & \\
\hline $\begin{array}{l}\operatorname{Raw}\left(\mathrm{cmH}_{2} \mathrm{O} / 1 / \mathrm{sec}\right) \\
\mathrm{Gaw}\left(1 / \mathrm{sec} / \mathrm{cmH}_{2} \mathrm{O}\right) \\
\mathrm{SGaw}\left(\mathrm{cmH} \mathrm{H}_{2} \mathrm{O} 1 / \mathrm{sec}\right) \\
\mathrm{MEF}(1 / \mathrm{sec})\end{array}$ & $\begin{array}{c}20 \cdot 54 \\
0 \cdot 048 \\
0 \cdot 014\end{array}$ & $\begin{array}{l}2 \cdot 36 \\
0 \cdot 42 \\
0 \cdot 164\end{array}$ & 二 & $\begin{array}{l}5 \cdot 86 \\
0 \cdot 17 \\
0 \cdot 085\end{array}$ & $\begin{array}{l}3 \cdot 30 \\
0 \cdot 30 \\
0 \cdot 18\end{array}$ \\
\hline $\begin{array}{l}\text { MIF }(i / \mathrm{sec}) \\
\text { MEF } \\
\overline{\text { MIF }}\end{array}$ & $\begin{array}{l}1 \cdot 10 \\
1.90 \\
0.59\end{array}$ & $\begin{array}{l}5 \cdot 40 \\
2 \cdot 66 \\
2 \cdot 03\end{array}$ & $=$ & $\begin{array}{l}3.35 \\
2.15 \\
1.56\end{array}$ & $\frac{4 \cdot 51}{1 \cdot 18}$ \\
\hline 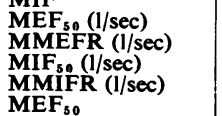 & $\begin{array}{l}0.66 \\
0.42 \\
1 \cdot 87 \\
1 \cdot 78 \\
0 \cdot 35\end{array}$ & $\begin{array}{l}3 \cdot 50 \\
2 \cdot 67 \\
2 \cdot 55 \\
2 \cdot 78 \\
1 \cdot 37\end{array}$ & $\frac{\overline{7}}{2 \cdot 73}$ & $\begin{array}{l}3 \cdot 00 \\
2 \cdot 35 \\
2 \cdot 15 \\
1 \cdot 75 \\
1 \cdot 28\end{array}$ & $\begin{array}{l}3 \cdot 35 \\
3 \cdot 16 \\
\frac{7}{0 \cdot 76}\end{array}$ \\
\hline $\begin{array}{l}\overline{\operatorname{MIF}}_{50} \\
\text { FEV }_{1 \cdot 0}(1 .) \\
\text { FIV }_{1 \cdot 0}(1 .)\end{array}$ & $\begin{array}{l}0.77 \\
1.49\end{array}$ & $\begin{array}{l}2 \cdot 32 \\
2 \cdot 37\end{array}$ & $\begin{array}{l}2 \cdot 09 \\
2 \cdot 32\end{array}$ & $\begin{array}{l}2.03 \\
1.53\end{array}$ & $\stackrel{2.42}{-}$ \\
\hline
\end{tabular}

Abbreviations as in text. Predicted values were taken from the following sources: Gaw, MEF, MEF 50 , and FEV $_{1.0}$ from Zapletal et al. (1969); MMEFR from Weng and Levison (1969); MEF/MIF et al. (1969); MMEFR from Weng and Levison (1969);
and $\mathrm{MEF}_{50} / \mathrm{MIF}_{50}$ from Jordanaglou and Pride (1968).

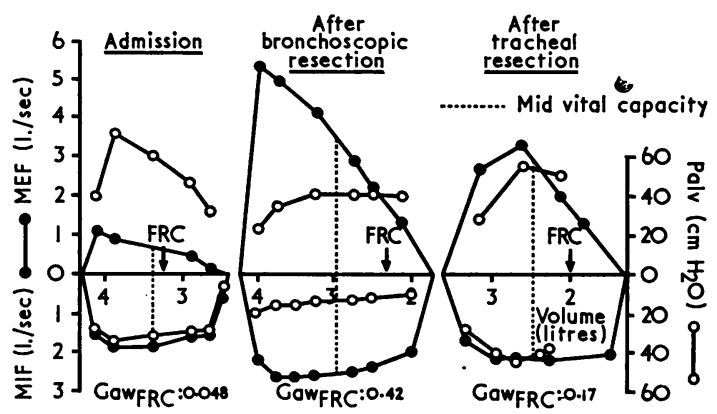

FIG. 5. Flow-volume curves on admission after endoscopic and surgical resection.

Postresection studies (study 2) showed that the hyperinflation was less and that airways resistance, expiratory flows, and the flow volume slope had become normal (Tables I and II, Fig. 5). Increase in inspiratory flows lagged behind and expiratory/ inspiratory relationships became higher than normal predicted values. However, this coincided with the development of relatively low alveolar pressures during inspiration. A normal inspiratory 


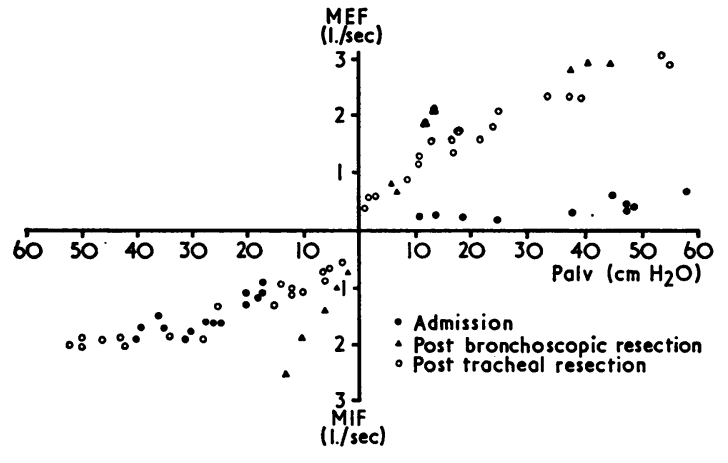

FIG. 6. Isovolume pressure-flow curves.

pattern was now seen in IVPF curves but an expiratory plateau was not obtained at maximal alveolar pressures of $40 \mathrm{cmH}_{2} \mathrm{O}$ (Fig. 6).

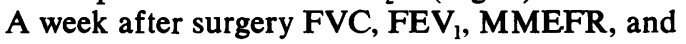
MMIFR were normal (study 3, Table II). Four weeks after operation a complete study was carried out (study 4). The flow-volume plot disclosed an important reduction in maximal expiratory flow rates when the lung volume was above 31 . Minor changes were observed in inspiratory flows (Fig. 5). However, the inspiratory IVPF returned to the abnormal, pressure-independent pattern previously observed on admission.

\section{DISCUSSION}

This report describes a rare type of tracheal tumour. From published reviews of tracheal tumours we have been able to find only three clearly defined instances of fibrosarcoma (McCafferty, Parker, and Suggit, 1964 ; D'Aunoy and Zoeller, 1931; Fourez et al., 1968). Two more have been published as single case reports (Richards and Dietrich, 1934 ; Vanetti et al., 1969).

Studies by Miller and Hyatt (1969) have categorized obstruction of main airways according to their dynamic behaviour. Fixed obstructions are those where a normal expiratory-inspiratory flow relation is preserved. Variable obstructions are characterized by a predominant decrease of expiratory flow, when they are intrathoracic, or of inspiratory flow when they are extrathoracic. The different pattern depends not only on the physical characteristics and location of the lesion but also on the dynamic behaviour of the rest of the airway. Intrathoracic tracheal tumours or fibrous stenosis which do not reach the thoracic inlet show predominant expiratory flow restriction. This is produced by dissipation of dynamic intraluminal pressures across the lesion and increased compression by high thoracic pressures on the thoracic tracheal segment distal to the stenosis. When the stenosis is extremely severe it may show a fixed pattern whatever its location. It is probable that this behaviour is observed when the calibre of the lesion is smaller than that produced during dynamic compression. Tracheal wall infiltration by the pathological process may also render it insensitive to pressure changes. The preoperative study in our patient showed hyperinflation with normal static recoil pressures and severe obstruction demonstrated by very low flows and conductance. A predominant decrease of expiratory flow is appreciated by the low values of the mid-vital capacity flow index. This pattern corresponds to a variable intrathoracic type of obstruction. Nevertheless the tumour was located outside the thorax. The obstructive pattern may be explained if it is accepted that this tumour, though implanted in the cervical trachea, could extend into the thoracic trachea without infiltrating its wall. This is possible since at bronchoscopy the tumour was soft and free in the lumen and there was no ulceration of the thoracic tracheal mucosa after its removal. It is feasible then that expiratory obstruction may be produced by decrease in lumen size by both the tumour and tracheal compression. During forced inspiration, on the other hand, inspiratory widening of the thoracic trachea and release of compression may allow higher flow rates. The effort-independent inspiratory flow patterns observed during the IVPF curves have not, to our knowledge, previously been reported. Nevertheless, we have frequently observed it in extrathoracic tracheal obstruction. The plateaulike effect might be tentatively attributed either to a mechanism similar to that postulated for the expiratory plateau or to increasing flow turbulence (Mead et al., 1967; Pride, Permutt, Riley, and Bromberger-Barnea, 1967). However, further studies will be needed to clarify this point.

We wish to thank Dr. Malcolm H. McGavran of Pennsylvania State University for reviewing the histological sections and Dr. J. J. Boretti who carried out the surgical treatment.

\section{REFERENCES}

D'Aunoy, R., and Zoeller, A. (1931). Primary tumors of the trachea. Archives of Pathology, 11, 589.

DuBois, A. B., Botelho, S. Y., Bedell, G. N., Marshall, R., and Comroe, J. H. Jr. (1956). A rapid plethysmographic method for measuring thoracic gas volume. A comparison with a nitrogen washout method for measuring functional residual capacity in normal subjects. Journal of Clinical Investigation, 35, 322. 
and Comroe, J. H. Jr. (1956). A new method for measuring airway resistance in man using a body plethysmograph: values in normal subjects and in patients with respiratory disease. Journal of Clinical Investigation, 35, 327.

Fourez, J. P., Moreau, G., Eschapasse, H., Delaude, A., Bolinelli, R., and Bolinelli, M. (1968). Les sarcomes broncho-pulmonaires primitifs. A propos de deux observations inédites. Revue générale de 130 cas. Revue de Médecine de Toulouse, 4, 289.

Jaeger, M. J., and Otis, A. B. (1964). Measurement of airway resistance with a volume displacement body plethysmograph. Journal of Applied Physiology, 19, 813.

Jordanaglou, J., and Pride, N. B. (1968). A comparison of maximum inspiratory and expiratory flow in health and in lung disease. Thorax, 23, 38.

McCafferty, G. J., Parker, L. S., and Suggit, S. C. (1964). Primary malignant disease of the trachea. Journal of Laryngology and Otology, 78, 441.

Mead, J., Turner, J. M., Macklem, P. T., and Little, J. B. (1967). Significance of the relationship between lung recoil and maximum expiratory flow. Journal of Applied Physiology, 22, 95.
Milic-Emili, J., Mead, J., Turner, J. M., and Glauser, E. M. (1964). Improved technique for estimating pleural pressure from esophageal balloons. Journal of Applied Physiology, 19, 207.

Miller, R. D., and Hyatt, R. E. (1969). Obstructing lesions of the larynx and trachea: clinical and physiologic characteristics. Mayo Clinic Proceedings, 44, 145.

Pride, N. B., Permutt, S., Riley, R. L., and BrombergerBarnea, B. (1967). Determinants of maximal expiratory flow from the lungs. Journal of Applied Physiology, 23, 646.

Richards, L. G., and Dietrich, H. F. (1934). Fibrosarcoma of the trachea. Annals of Otology, Rhinology and Laryngology, 43, 892.

Vanetti, A., Maurel, A., Carnot, F., Lemoine, G., Galey, J. J., and Mathey, J. (1969). Fibrosarcome intra et péritrachéal opéré par résection et plastie selon la technique de Gebauer. Presse Médicale, 77, 2007.

Weng, T. R., and Levison, H. (1969). Standards of pulmonary function in children. American Review of Respuratory Diseases, 99, 979.

Zapletal, A., Misur, M., and Samanek, M. (1971). Static recoil pressure of the lung in children. Bulletin de Physiopathologie Respiratoire (Nancy), 7, 139.

- Motoyama, E. K., van de Woestijne, K. P., Hunt, V. R., and Bouhuys, A. (1969). Maximal expiratory flow-volume curves and airway conductance in children and adolescents. Journal of Applied Physiology, 26, 308. 